\title{
Break-off Environmental Caging: Agenda to Encourage the Birth of Local Government Biodiversity Reporting in Indonesia
}

\author{
Ratna Ayu Damayanti' ${ }^{1}$, Syarifuddin ${ }^{2}$ and Rahmawati H.S ${ }^{3}$
}

\author{
${ }^{1}$ Hasanuddin University, Indonesia \\ ${ }^{2}$ Hasanuddin University, Indonesia \\ ${ }^{3}$ Hasanuddin University, Indonesia
}

\begin{abstract}
In recent years many authors have called for the broad integration of ecological principles into planning to improve conservation of biodiversity. Based on this, the issue of this research is to link the relationship between planning and biodiversity, namely the extent to which local planning units overcome biodiversity conservation in their planning and policies. The purpose of this study is to uncover problems and information needs on the environment. To achieve these objectives, the researchers first identify environmental issues, especially related to biodiversity which is a significant issue in the local government, then mapping the need for reporting biodiversity accounting. This study operates discourse analysis methods. Discourse in this perspective is interpreted as multiple and irregular pronunciations, then using universal norms or standards will organize regular meanings. The findings of this study show that environmental problems raise some anxiety about ecological damage. The rapid development of urban development is one of the main driving factors in the emergence of environmentalism movement and increases the need for the importance of reporting biodiversity accounting as a form of government accountability.

Keywords: accounting, biodiversity, environment, public sector, the regional government
\end{abstract}

\section{Introduction}

Biodiversity, or sometimes referred to the many lives on earth, is something that all living things are dependable of, as well as something crucial. They are essential for the welfare of the planet and, in particular, for humans living on this earth (Jones and Solomon, 2013). The need to preserve the natural environment and biodiversity is a very urgent issue because of how species extinction is increasing at an alarming level, almost entirely from a direct result of human activities.

Therefore, recognition of biodiversity and global growth in economic development is essential. In this regard, The United Nations (UN) made 2010 the start of "International Year of Biodiversity." This declaration was carried out to reduce biodiversity loss caused by human activities, as well as United Nations General Assembly claiming that 2011-2020 as a decade which UN will focus on biodiversity. The United Nations Environment Program (UNEP) is one of the departments of the UN which plays a significant role in developing and advancing the international agenda toward creating biodiversity using the Strategic Plan for Biodiversity 2011-2020. This institution designs a 10-year strategic plan framework so that all countries and stakeholders will take action to save biodiversity and increase benefits for the life of all living beings. This framework does involve not only private organizations but also government organizations, including local governments.

As a framework for the conservation of biodiversity in the coming decades, the strategic plan aims to integrate biodiversity into the planning and performance of management at each level of government. The National Strategy stated that "[...] biodiversity in local government through its role in local and regional planning and, increasingly, through its role in environmental management, monitoring and reporting" (AGDE, 2010, 69). Related to this statement, the local government, therefore, is an essential partner in monitoring the local and regional environmental conditions holistically, whose acts manifest in every policy's action and responsibility.

As is known, decisions regarding the development of urban, suburban and former urban areas at the level of government, such as regencies or municipalities are seldom comprehensively made 
(Lawrence, 2005; Azerrad and Nilon, 2006). As a result, planning the land usage at a local scale does not consider the loss of habitat and nature of species resident in the area (Steelman, 2002). In recent years many authors have called for a full integration of ecological principles into land usage planning to improve biodiversity conservation (such as Beatley, 2000; Groves, 2003; Radeloff et al., 2005). Preservation is needed by farmers to keep their land productivities (Ady, 2015). Based on these facts, few questions come to mind regarding the relationship between planning and biodiversity, namely the extent to which local planning agencies addresses biodiversity conservation in their plan and policies. Do policymakers follow the guidelines offered by academics, natural resource institutions, and non-governmental organizations? How full is the implementation of land use planning tools to achieve conservation goals?

Academic scholars are also criticized in this regard because of how they put a low priority on biodiversity by giving little attention to accounting for biodiversity. Apart from Jones's main work (1996, 2003) which explores and operationalizes the concept of essential supplies, and some newer literature (Houdet et al., 2009a; Houdet et al., 2009b), it is plain to see that there is a lack of involvement of accounting experts. The challenges and criticisms in accounting relating to nature and natural resources influence this reluctance in accounting community (see Cooper, 1992; Hines, 1991; Lehman, 1999; Maunders and Burritt, 1991; Milne, 1991). Although accounting academics seems doubtful and disinterest to deal with biodiversity accounting seriously, the practitioners in the company is looking for models to insert biodiversity into their environmental management and reporting programs.

Research Problem. The reconstruction of the city is essential and has become a heated discussion at every international conference on the environment. Revitalization of the city, or known as urban renewal, was built and sought to reorganize a region to get enough added value as well as to maintain preservation of function and quality of the environment (Jones, 1996). Urban renewal is not something new because it has been introduced since the eviction of old facilities and infrastructure, environmental damage, and social damage to the inhabitants occurs. Therefore, in Indonesia, the city rejuvenation policy should be carried out with extreme caution, after reflecting on the experience of failure in other countries that have previously implemented the plan. There needs to be an appropriate, effective, and efficient approach strategy in the spirit of achieving a sustainable city environment by involving all stakeholders, including the role of accounting academics. The purpose of accounting researchers is to assess and measure the social and ecological losses that arise due to growth in urban areas or densely populated areas.

The problem of city ecosystem imbalance has become a significant problem in cities in the world, including Indonesia, which has been going on since the Industrial Revolution in the late 19th century that spurred economic growth as well as the transformation of people's social lives. With the consumption of resources is increasing, the city becomes densely populated with deficient environmental carrying capacity. At the end of the 20th century, most countries in the world experienced an economic crisis with negative economic growth. However, this condition did not necessarily reduce the impact toward the urban environment that had already been damaged by previous economic developments. Instead, recent events show that environmental damage is increasing (Kelly, 2008).

As an illustration, the rapid growth in urban areas hampers production and consumption activities by depleting some or all the resources, such as water, energy, and land. The utilization of land and water resources tends to be carried out without regard to environmental carrying capacity, thus threatening the sustainability of ecological functions and sustainable urban development. The result of this rapid growth impacts natural resources utilization in the city and all its hinterland, which is far more extensive than the city boundary itself. Additionally, resource consumption is more severe in industrial cities because of how it drains resources on a large scale.

The production of merchandise, the replacement of energy and materials, as well as transportation services, are all concentrated in big cities is a fact that does not need to be debated anymore. 
Therefore, the big city is not only responsible for its local environmental situation but also increases in global ecological problems. Cities are places where issues of resource consumption and ecological pollution occur, and areas where forms of economic growth that threaten natural resources and ecosystems of the world can be felt very clearly and continuously. Also, the open process of urbanization does not only cause problems of social loss but also creates ecological issues, including environmental degradation.

Related to the problems faced by urban areas listed in this paper, the researcher adopted the view that "accounting for biodiversity" can be sorted into a series of issues. Based on this idea, the research problem can be formulated as follows: how to map environmental issues and biodiversity accounting information needs that should be accommodated in government accountability reports related to biodiversity?

In this case, researchers seek to map environmental problems and information needs in "accounting for biodiversity." To achieve this, researchers first will need to identify issues related to biodiversity which is becoming a significant issue in local government. Secondly, researchers categorize and classify information that is suitable for reporting by the local government. Thirdly, researchers identify and analyze user's information that is related to accounting biodiversity. Hence, this will show that the demand for transparency of local government does not only focus on activities that have financial consequences but also consequences for environmental degradation.

Problematization as an approach to identify and analyze the "problem," which are the cause and the actors involved, has been applied in various contexts of accounting (see Georgakopolus and Thomson, 2005; Solomon and Thomson, 2009). Tregidga (2013), was one of the contributors who develop a detailed theoretical framework for accounting problematization on specific biodiversity issues. He used a conceptual framework of governmentality, which comes from the work of Foucault whom the first source was from Dean's governmentality framework, to map the biodiversity offsetting (biodiversity replacement). In this study, the researcher will discuss in more detail in emphasizing the importance of mapping problems and benefits of implementing the problematization techniques to identify, analyze, and provide solutions to accounting biodiversity issues in local governance.

To assess the quality of sustainability reporting from government organizations, some researchers use benchmarking studies by comparing reporting with the Global Reporting Initiative (GRI) framework. In a survey of sustainability reporting in the Australian public sector organizations, Guthrie and Farneti (2008) examine sustainability reporting patterns on seven organizations (the three is a local government organization) with the GRI G3 Guidelines. Their research findings show that only 32 of the 81 elements of the GRI are used when reporting. These organizations choose GRI indicators following the disclosures they want related to community complaints and leave the reader to conclude their analyses of the reports. Such forms of reporting are too general for public sector organizations. According to Guthrie and Farneti $(2008,366)$, reporting on the sustainability of public sector organizations are still in development because of the information inconsistencies reported where several GRI elements are still prone to be confidentiality. This can be an implication for future policies and research. Although public sector organizations have done some sustainability reporting, the gap similarity and consistency of reporting models still require further study (Williams et al., 2012; Marr, 2006)

Commenting on the study of Guthrie and Farneti (2008), Ball and Bebbington (2008) wrote that incompleteness of documents when reporting under the GRI guidelines of sample organizations did not show good results, or for publishing in the public sector in general. They address the need for sustainability reporting guidelines that are common to public sector organizations, as this organization has specific characteristics and context in which they operate, it will then lead to the sustainable development agenda that runs differently (and potentially more effective). Adopting benchmarking approach on the GRI framework for the public sector organization once again can be a futile activity considering the status quo in the area of research in that area and given the different focus of ongoing research. 
Meanwhile, Goswami and Lodhia (2014) use a case study method in the analysis of the sustainability disclosure in four of 68 local governments in South Australia. Their study was supported by previous studies (Sciulli, 2011; Guthrie and Farneti, 2008) which found that local governments did not widely use GRI guidelines, and they also found that sustainability reports were not a separate report or a new form of the story. Goswami and Lodhia $(2014,279)$ recognize that: "[...] it would be impossible to draw decisive and general conclusions about the other 64 South Australian councils because four councils are not representative of the diverse nature of all South Australian local councils".

Goswami and Lodhia Study (2014) has implications for future studies, where they emphasized the need to examine disclosure content, and do not assume that the results of the disclosure are at a low level if not following standard reporting guidelines (e.g., GRI). Therefore, the approach of the case study conducted by Goswami and Lodhia (2014) does not suggest a benchmarking approach. Their research can be an illustration in this study that emphasizes disclosure content and case studies when providing significant in-depth information about the biodiversity within an organization that is used as the object of research. Also, the time needed is longer so that the researcher gets a broader picture to develop a biodiversity reporting model for regional government in Indonesia. This is because the objective of this study was to explore the sustainability of some countries reporting both the developed and developing countries with the focus on biodiversity as a basis to prepare for research and observing disclosure content for the development of a biodiversity reporting model in Indonesia. Furthermore, maintaining a stable inventory of natural assets is part of the role of society and government (Jones, 2003). Therefore, policy and policy reporting on biodiversity is critical as a commitment to manage biological resources. Application of policies and biodiversity reporting objectives at the local level influence awareness for stakeholders on the needed information related to the availability of specific wild fauna populations present in both regional and national databases to make policy (Raar, 2014).

Past research on environmental accounting has been dominated by concentrating on studies on social and environmental disclosure. This researches were the reasons for proposing environmental exposures (Gray et al., 1993: Gray and Bebbington, 2001), measuring the level of exposure (Harte and Owen, 1991; Roberts, 1991; Hackston and Milne, 1996; Deegan et al., 2002), and a recent study conducted by Magness (2006), Cho and Patten (2007), next was the research that captures managerial motivation to make such disclosure (Deegan et al., 2002; O'Donova n, 2002; Cho and Patten, 2007; Grabsch et al., 2010; Laine, 2009). Meanwhile, Gray et al. (1995) provide a review of alternative theoretical approaches used in the literature of social and environmental accounting disclosure and identifies relevant theories such as stakeholder theory, the method of legitimacy, political and economic theory, as the main theoretical approaches used to examine the disclosure of environmental accounting.

Stakeholder theory shows that a company's environmental disclosure practices are formed by three factors, namely, stakeholder strengths, company profiles, and profitability (see Ullman, 1985; Roberts, 1991; and in the context of developing economies, Elijido-Ten et al., 2010). Meanwhile, the theory of legitimacy has been widely applied in the environmental accounting literature to explain the managerial motivation to disclose ecological information (for example, see Deegan, 2002; O'Dwyer, 2002). According to this theory, the disclosure of a positive environment can improve or restore the legitimacy of the organization (Milne and Patten, 2002; Mobus, 2005). Also, Jones (2010) discussing the main theoretical approaches to environmental accounting, and he mentioned that the organization's efforts to promote the environment and working conditions that are "green" could also help to gain legitimacy. Apart from these two dominant approaches, Gray et al. (1996) offer insights from the side of political, economic theory to help understand organizational social and environmental activities. They claim that for the organization of economic activity analysis more meaningful, the socio-political environment in which it operates must be taken into consideration. Jones (2003) proposes a theoretical approach that explains the need to operationalize environmental accounting. This paper uses ecological stewardship as the central theoretical premise to operationalize 
biodiversity accounting. Ecological stewardship is defined as, "as the comprehensive understanding and effective management of critical environmental risks and opportunities related to climate change, emissions, waste management, resource consumption, water conservation, biodiversity protection, and ecosystem services" (UN, 2010, 9). Based on this approach, organizations are considered to be responsible for society in general to protect the environment. It is said that in addition to following the laws and regulations, organizations also gain legitimacy through their performance on social, moral responsibility collectively, and environmentally responsible is a significant part. Guimaraes and Liska (1995) found that companies that demonstrate a higher level of concern for the environment tend to benefit more than a company that only minimally complied with legal requirements.

Jones (2003) argues that stewardship is a broader context of ownership, and organizations do not have the right to waste natural assets because there are more general social considerations. This paper shows that an essential part of environmental stewardship is the maintenance of the supplies of physical assets. As a note of supplies can be expanded his understanding of double-entry bookkeeping to take into account the physical assets (for example, land degradation (Rubinstein, 1992)). In the management literature, the concept of environmental stewardship has mostly been applied to the operationalization of business in the private sector, while the role of government in environmental stewardship often overlooked. However, the application of the concept of environmental stewardship in the public sector is not new. Through several types of research, it can be seen that governments in various countries have used environment management as their key performance indicators (e.g., Mohninger, 2000 in Ghana; Ramos et al., 2007 in Portugal). This shows that efforts to operationalize biodiversity accounting in the context of the public sector are becoming more relevant.

Based on the framework of Gray (1992) on natural assets, Jones proposed an essential supplies model in which he distinguished between information on the physical assets of "critical" and "non-critical." Critical natural capital is classified as "elements that are important for life on earth. Thus, sustainability must remain treated respectfully" (Barton, 1999). Therefore, critical natural assets are irreplaceable. Meanwhile, noncritical natural assets or "sustainable" natural assets, on the other hand, can be renewed. Natural assets in this category include the management of forests and species of flora and fauna that are in no threat of extinction. Jones (2003) reports that developed countries usually protect critical natural assets through the creation of restricted areas or protected areas.

Similarly, the availability of data in developed countries caused quantification of some natural assets (such as plants) become abundant, as the phrase Jones $(2003,768)$ : "geographically, the picture is mixed. In developed countries, there is enough taxonomic information. By contrast, in developing countries, information is more limited and fragmented".

Jones $(1996,2003)$, therefore, is one of the most productive academia in the field of biodiversity accounting research. In an exploratory research article published in The British Accounting Review, Jones (1996) pioneered the idea of mainstreaming biodiversity accounting in the practice of environmental reporting of an organization. Jones (1996), using a multidisciplinary approach, propose a model for recording, monitor and report on the inventory of natural capital. The purpose of this model is to provide a comprehensive framework in which data on physical assets can be recorded for stewardship purposes and reported to stakeholders as a form of accountability.

\section{Research Methodology}

This research uses discourse analysis to explore the phenomena. Fairclough (1997) recorded about eight discourse analysis approaches including analytical, linguistic, post-structuralist, semiotic, cultural studies, and social theories. Positivism's empirical epistemology approach gives birth to the notion that language is a small-medium of communication. Writing in this episteme is interpreted plainly. Expression is seen merely as a tool for expressing thoughts and feelings, for expressing love and art, for persuasion, and a vessel for conveying and preserving wisdom, as well as values upheld by a community. As far as being able to use accurate statements, according to syntactic, semantic, logical rules, and using empirical data as support, language users in this view are considered to have 
cognitive mental abilities that are free from distortions. In this epistemic view, patterns and meaning relationships in language can be studied discretely or autonomously without other information references. In analyzing a speech, for example, references to the ins and outs of the speaker are not so necessary. The reviewer only needs to concentrate his study on the intended text or speech text and see the meaning of the speech based on the semantic/syntactic rules of the book.

Discourse in this perspective is interpreted as complex and regular pronunciations, which follow certain norms or standards and in turn organize irregular reality. The rule or standard furthermore considered to be involved in composing human behavior, by entering specific appearance episodes in political, social, or other social relations categories. This view implies that rules, norms, or standards (in this case syntactic and semantic) determine the value of a discourse. To put it merely, speech is defined as units of language larger than sentences, often in the form of a coherent unit/coherent, purposeful, and specific contexts, such as religious lectures, arguments, jokes or stories. The elements of continuity and coherence are essential to assess a discourse. Furthermore, speech refers to "a collection of statements written or spoken or communicated using signs." Data obtained from both literature/documentation studies and field research in the form of observation and interviews will be analyzed using discourse analysis methods.

This research was conducted in 5 (five) regencies/cities namely city of Makassar, Gowa, Maros, Luwu, and Barru. Municipalities and districts are chosen because they are a region of rapid economic growth (Makassar, Gowa, and Maros), while the other two areas are an area rich in natural resources (Barru and Luwu). Research informants are local government officials who are related to the environment and citizens of environmentalists. The number of informants interviewed for each area is around 15-20 people varied depending on the information needed. The techniques used are various, such as face to face interview, focus group, snowball and other technologies as required in the field. Discourse analysis is a study of the use of language which has the purpose of showing and interpreting the existence of a relationship between the order or patterns with the goals expresses through the language unit. The discourse analysis of the Norman Fairclough is carried out through surgery and careful observation of linguistic elements such as cohesion, ellipsis, conjunctions, information structures, themes, and so on to show the meaning that is not visible on the surface of discourse. For example, a conversation that does not physically have cohesive links can be a coherent discourse in specific contexts, while a sentence group that has consistent links does not or does not necessarily become a cohesive discourse, so it can be concluded that the existence of cohesive links does not guarantee a dialogue. Therefore, knowledge is needed about the function of each utterance that exists to understand discourse.

In connection with the reporting of biodiversity, the researchers will use coding to the theme of biodiversity in accounting reports that are derived from existing literature and GRI indicators developed by Grabsch et al. (2011). This encoding is divided into seven categories: (1) scene-setting; (2) related species; (3) social engagement; (4) performance; (5) risks; (6) internal management; and (7) external reporting.

\section{Result and Discussion}

Metropolitan areas in Indonesia generally cannot afford to create adequate green space. City development policies often sacrifice green regions and cannot guarantee their sustainability and expansion. For example, road construction is usually followed by the feeling of shady trees that take decades to grow. Creation of various trade facilities and shops is not accompanied by the creation of city parks insufficient area. As a result, urban areas do not have the lungs of a city that is sustainable and air health is getting worse. This is compounded by the free use of ozone-depleting substances due to the use of air conditioning. According to the informant who is also an environmental observer: Several cities in Indonesia are currently facing increasingly poor environmental health conditions. Just look at the port of Makassar which tend to consider the health of a bad urban environment as usual, even though they often complain and criticize. Inadequate urban infrastructure and facilities 
make city residents vulnerable to health, such as infectious diseases, water pollution, and contaminated food. One of the worst facilities in cities in Indonesia, including our city (Makassar), is the uncontrolled drainage and waste management. Drainage channels are mostly small and clogged, due to the garbage disposal. Liquid waste directly flows into the river without prior processing. (italics as an explanation).

This shows that residents of various cities that are used as observations face the dangers that arise from increasingly poor water quality. In general, city residents rely on surface water with increasingly poor quality. This condition is worsened because residents do not have adequate sanitation facilities. Even more unsettling, the city government is unable to relocate industries that mostly dumped hazardous waste into water sources. Although, some of the more capable urban residents can indeed use clean water which is channeled through pipes. This water resource is, and its availability is uncertain, and the quality is not good.

Furthermore, city governance is inadequate and does not support rapid and sustainable urban growth. City management is more often seen as the duty and obligation of the city/regional government alone, while citizens are passive or just demand the facilities, they value necessary. If the government fails to provide a variety of facilities and comfort, the residents will stay silent or protest. They did not carry out a broader and more in-depth analysis to find out how poor urban governance is and did not provide various change efforts needed to improve city governance, for the sake of enhancing and realizing sustainable urban governance. This is due to the unavailability of local government accountability reports to stakeholders on environmental management and biodiversity. Thus, the community is unaware of what to do.

These are the problems that are found in many urban environments, and thus as a community, we should be responsive and observant in choosing the city where we live so that we can avoid the problems above. The dominant urban environmental issues are the population and building density of the city that continues to increase, in addition to the question of solid waste, urban sanitation, and water quality. The question of a densely populated city becomes more complicated with very high population growth, especially the non-permanent population. The population is the biggest threat and pressure on environmental problems. Every community needs a lot of energy, land, and resources to survive; on the other hand, everyone produces waste in various forms. Very high population growth in the city has been recognized to be beyond carrying capacity of the environment to regenerate itself. Thus, the impact on the quality of human life lowers.

Solid waste problems in urban areas are mainly due to the amount of garbage dumped into the river body or scattered in the open. With a lot of garbage, the river cannot function properly (transportation, conservation, recreation, etc.) due to water that does not flow smoothly and damages river biodiversity due to harmful substances contained in the waste. In addition to the problem of garbage in the river, the landfill in various corners of the city has the potential to cause various diseases, especially diseases caused by mosquitoes, flies, cockroaches, and rats. The existence of flies, mosquitoes, and rats which is a carrier multiple kind of conditions become one indicator of how good the quality of a city is. It is even indicated that the cause of global warming is not only due to excessive $\mathrm{CO} 2$ production, but also caused by $\mathrm{CH} 4$ substances produced from the process of burning waste carried into the atmosphere and damaging the ozone layer.

Furthermore, waste management that still uses the old paradigm (collection, transportation, and final disposal) needs to be changed. This is because the problem of waste is increasingly complex, especially the difficulty of obtaining a landfill, as well as the growing number and variety of urban waste. Waste management with a new paradigm needs to prioritize the process of waste reduction and utilization (waste minimization). Waste minimization is an effort to reduce the volume, concentration, toxicity, and level of danger of waste coming from the production process by reducing the source and utilization of waste. The advantages of this method are: reduce dependence on landfills, improve the efficiency of urban waste processing, and create business opportunities for the 
community. The waste minimization method includes three essential businesses known as 3R, namely reduce, reuse, and recycle.

Meaning, environmental problems in large cities or densely populated areas are a threat to society today or in the future, namely human-caused damage to their physical environment. Urban environmental issues raised by initiators of urban development that are in regard to ecological issues refers to environmental health problems such as drinking water and inadequate sanitation, air pollution, and overcrowding in the room; regional problems such as air pollution, improper waste disposal, pollution of water bodies, and the loss of green areas. Meanwhile, according to informants interviewed, "regional or global environmental burdens arising from activities at the outside of the city's geographical boundaries will affect people living in the area." Furthermore, another informant, a female environmental observer, argued that :

There are several environmental challenges that arise in big cities. The problem faced are how the government must be able to provide essential ecological services in ways that are most effective in protecting health. Access to sanitation that is safe to drink, maintain water quality, and drainage facilities. Proper management of garbage collection and disposal. Pollution reduction in households by providing clean fuel for cooking and improved household ventilation.

Additionally, another problem identified is poverty in densely populated areas because urban poverty and environmental conditions are interrelated. Debt has reciprocal causality with the environment because poverty can cause ecological damage, and ecological threats can exacerbate poverty. Poverty is further compounded by environmental risks that result in bad health, the onset of death, and suffering for humans.

Also, the influence of urbanization can also be a factor causing environmental problems in densely populated areas and crowds. Urbanization causes the population to increase in urban areas, and this result in a decrease in space available caused by land used for settlements. Furthermore, for immigrants who are unable to find any agreement become the low class and poor in urban areas. As said by the informant, that "the capacity of the city for population growth continues to be eroded, the migrants occupy slums area that can be said to be inappropriate as residential."

Based on the results of literature studies and field observations in the study area, it appears that human activities both directly and indirectly have an impact on environmental damage, such as 1) Illegal logging (deforestation); 2) Forest destruction for livelihoods; 3) Clogging of swamps for settlements; 4) Disposal of garbage in any place; 5) Slum in the watershed; 6) Excessive use of natural resources beyond the limits. This complete information should be reported by the local government to stakeholders as a form of accountability for environmental management and biodiversity. Living without adequate accountability reports lead to ecological problems increasingly expanding, like a snowball rolling down, it grows and the impact it causes will worsen.

The problem is not only local or trans local, but regional, national, trans-national, and, ultimately, global. For example, the case of burning peat forests in Kalimantan for community crop fields have the impact of air pollution in the form of thick smoke to neighboring countries such as Brunei, Singapore, even to Malaysia. The results that occurred on the environment may be related only to one or two aspects, but the association following the nature of the environment has a multi-chain relationship, and each influences the other in the sub-system. If an element of the situation is affected by a problem, then various other aspects experience an impact or effect. In the beginning, environmental issues were a nature issue, namely events that took place as part of a natural process, which does not have significant consequences for the ecological system itself and could recover naturally in the future.

However, at present, the environmental problem can no longer be said as a problem that is merely natural, because humans provide a variably significant effect toward ecological events. Also, environmental issues are born and developed because of human factors are far higher and more complex than the natural elements themselves. Thus, the physical recovery of the environment becomes unable to compensate for the damage done by humans. 
Furthermore, humans with their various dimensions, especially with their mobility factors, the growth of the mind with all developments in aspects of culture, and with the process of the times that change human character and outlook, accelerate the process of damage, especially environmental processes in urban areas. Therefore, current environmental issues such as pollution, damage to natural resources, depletion of forest reserves, destruction of various biological species, erosion, flooding, and even multiple types of diseases that developed recently are believed to be negative symptoms that are predominantly sourced from human factor itself. Thus, it is reasonable to say that where there are environmental problems, there are humans, or vice versa, where there are humans therefore ecological issues arise.

Therefore, in the framework of preventive and possessive to overcome environmental problems, then each action will not be valid if handled with the paradigm of physical, scientific, and technological or economic. But the solution according to Hines (1991) is through a humanistic approach, which involves all aspects and roles of science such as sociology, anthropology, psychology, law, health, religion, ethology, and so on. All elements are involved and become strategic to overcome environmental problems and urban problems.

Finding A Solution: Improving Human Behavior Toward Their Environment. As human beings who have reason, mind, and instinct, people should be able to see the various phenomena of disasters that often occur this country, Indonesia. Not merely to see, but a community should be able to analyze the causes of the failure to be able to think about and carry out preventive actions to prevent similar accidents.

In this case, environmental management issues should be considered as one of the leading causes of natural disasters in Indonesia. According to the informant,

The root of all environmental problems is development carried out without regard to ecological balance factors, which in turn will damage the environment. Construction of residential, industrial, or plantation areas often ignores environmental sustainability and only considers aspects of economic benefits. As a result, there is ecological damage that triggers disasters such as examples that we see in the mass media.

Furthermore, environmental management errors can be caused by various factors such as level of education, the economy, lifestyle, the weakness in regulations, and weak oversight of ecological management. An informant stated that:

To overcome the problem in environmental management, there must be at least some elements that producers and consumers who utilize resources have, such as ecological awareness, legal awareness, and commitment to protecting the environment. These three aspects... most people in Indonesia still do not realize the importance of integrated environmental management and sustainability. Many people from the community (from established economies to lower middle class, farmers to investors) who do not have adequate ecological awareness. A simple example of the above statement is the widespread use of pesticides in agriculture. For the sake of good yields, farmers use chemical pesticides to eradicate pests and weeds, without realizing that this is very dangerous because chemical pesticides kill not only pests but also another biota that are useful. Even worse, it is rarely heard that an agricultural extension agent gives knowledge about the dangers of using chemical pesticides to farmers so that the use of chemical pesticides remains rampant.

In everyday life, we can also see various examples of inaccuracy in environmental management. In line with the pace of national development that is carried out, environmental problems must be managed, such as damage to the environment around the mining area that has the potential to damage the landscape, as well as overlapping of land use for mining in protected forests. Cases of environmental pollution also tend to increase. The progress of transportation and industrialization which is not accompanied by the application of environmentally friendly technology has a negative impact, especially on the urban environment. According to an informant: 
Industrial waste and households pollute rivers in the city. Soil conditions are increasingly polluted by chemicals both from solid waste, fertilizers, and pesticides. This pollution problem is caused by the low awareness of business and the public to live clean and healthy with good environmental quality. While other informants stated: The flaw in implementing environmental regulations that are prominent is in law enforcement and accountability reporting for ecological management. The rapid growth of national development that aims to improve the welfare of the community is not matched by the adherence to rules, especially concerning the social and environmental fields by the development party, thus causing environmental problems. The government must account for all of this in a transparent report.

Based on the results of observations in the field, even though the government through the environment ministry has asked the regional government to make a biodiversity report, only a handful of regions have implemented the regulation. Biodiversity reports produced by the Indonesian local government are reports on information on the performance of local environmental management and biodiversity profile reports. This report is made on instructions from the environment ministry based on the State Regulation of the Environment No. 29 of 2009 concerning Guidelines for Biodiversity Conservation in Regions. However, this report based on observations in several regions, not all parts make it. Also, the information contained in the story was extensive, so that the reports produced were very thick in the number of more than 500 pages, which resulted in the report being non-communicative and not informative. In the end, the critical issues related to biodiversity that the local government wants to be reported becomes unimportant because it is difficult to understand by stakeholders. As a result, stakeholders' participation in environmental management becomes impossible with how thick the information is provided. In other words, instead of environmental problems getting lighter, it gets more substantial with the thick reporting that was made.

Biodiversity Report Form: Reflection of Daily Issues in Local Government. The critical question is whether general accounting is suitable for accommodating biodiversity reporting? The answer is that accounting practices have evolved over centuries and are designed for financial calculations, and, the formation of equity and profits. In this regard, Jones $(2010,129)$ concludes that general accounting is not designed to discuss the environment, because it does not capture human impacts on the natural environment. He underlined the orientation factors of capitalism, business focus, dependence on neoclassical economics, numerical quantification, financial dependence that led to conventional accounting practices unable to describe the problems faced by the environment in general, let alone about the biodiversity environment. Thus, based on this study, it can be said that general accounting does not accommodate biodiversity reporting because it does not address environmental issues at all. Therefore, from the perspective of accounting science, accounting reporting needs to change so that environmental factors can be accommodated, mainly reporting on biodiversity.

This is following Gallhofer and Haslam $(2011,501)$ who states: "accounting can shape reality, construct reality. Accounting is not a neutral function, a series of calculative devices which relate historic data merely as an information gathering exercise. Accounting has distinct emancipatory potential". Biodiversity accounting, therefore, (in regard to disclosing, measuring, and reporting for biodiversity) makes, that according to the capitalists, as something unreal into something real.

Biodiversity accounting reporting is essential according to this study, in line with Buhr's view that accounting can change human behavior. As he said (2007, 44),

accounting for biodiversity can shape the way in the society perceives and understands the social role in species extinction. By reporting on biodiversity corporations (and government) can create a more informed community, impacting the evolution of the understanding of biodiversity impacts and transforms both attitudes and behavior about biodiversity (italics is the author's emphasis).

\section{Conclusion}

Since the issuance of scientific research reports by academics on the level of carbon dioxide accumulation in the Earth's atmosphere, there have been some concerns about ecological damage. A 
fear that arises was due to the phenomenon of climate change with the depletion of the ozone layer, global warming, and the occurrence of acid rain. The rapid development of the scientific literature publication also became one of the main driving factors in the emergence of environmentalism. There are two views related to the relationship between humans and nature, namely anthropocentric and biocentric views. An anthropocentric view states that the environment or life is something that humans naturally use, as well as to be exploited. Anthropocentricity also results in stratification between humans and nature, by placing nature status as beneath human. The emergence of this view was triggered by the Industrial Revolution which then had implications for the development of industrial society and the materialist view, the massive exploitation of natural resources, and consumption becoming a commonplace the middle of the 20th century. Indicators of economic success are then assessed based on GNP levels, industrial expansion, and various other material matters. These things show that human progress is only seen through exact and material values.

The arguments built by this study come from the perspective of the environmental crisis, as well as the idea of decentralization to address environmental issues. This study considers that action is needed on a global scale to address the environmental problems, however, this study also supports that work on a small community scale is also required to preserve the environment. This may be slightly different from the views of supporters of green theory who reject the state system to address environmental issues both locally and globally. This is because this study considers that the world consists of a global network that contains small communities with close links with one another based on the use of resources. These small communities are the answer to the environmental crisis because this community interdependence can lead to a responsive attitude, as well as an act of accountability to the environment.

\section{References}

Ady, M. M. A. (2015). Findings in Interviews on Motivation of Farmers for the Improvement of Paddy Rice Quality and the Implementation of New Methods of Paddy Rice Production in the Chiba Prefecture. 人文社会科学研究 第 31 号. Retrieved from https://core.ac.uk/download/pdf/97064981.pdf

Australian Government, Department of Environment (AGDE) and Natural Resource Management Ministerial Council. 2010. Australia's Biodiversity Conservation Strategy 2010-2030. Water, Population and Communities. Canberra available at: www.environment.gov.au/system/files/resources/d233f869-fae7-4311-89d1-11556179db29/ files/biodiversity-strategy-2010-brochure.pdf (accessed at 24 January 2017).

Azerrad, J.M., \& Nilon, C.H. (2006). Evaluation of agency conservation guidelines to better address planning efforts by the local government. Landscape and Urban Planning, 77. pp. 255-262

Ball, A., \& Bebbington, J. (2008). Editorial: accounting and reporting for sustainable development in public sector organizations. Public Money \& Management, Vol. 28 No. 6. pp. 323-326.

Barton, A.D. (1999). A trusteeship theory of accounting for natural capital assets. Abacus, Vol. 35 No. 2. pp. 207-222.

Beatley, T. (2000). Green Urbanism: Learning from European Cities. Island Press, Washington.

Buhr, N. (2007). Histories of and rationales for sustainability reporting. In Unerman, J., Cooper, S.M., \& Owen, D.L. (Eds). Corporate Social Reporting and Stakeholder Accountability: The Missing Link. Routledge: Oxford. pp. 649-667.

Cho, C.H., \& Patten, D.M. (2007). The role of environmental disclosure as tools of legitimacy: a research note. Accounting, Organisations and Society, Vol. 32. pp. 639-647.

Cooper, C. (1992). The notion and nom of accounting for (m)other nature. Accounting, Auditing \& Accountability Journal, Vol. 5 No. 3. pp. 16-39.

Jones, M. (1996). Accounting for biodiversity: a pilot study. British Accounting Review, Vol. 28. pp. 281-303. 
Deegan, C. (2002). Introduction: the legitimising effects of social and environmental disclosures - a theoretical foundation. Accounting, Auditing, \& Accountability Journal, Vol. 15 No. 3. pp. 282311.

Deegan, C., Rankin, M, \& Tobin J. (2002). An examination of corporate social and environmental disclosures of BHP from 1983-1997. A test of legitimacy theory. Accounting, Auditing, \& Accountability Journal, Vol. 15 No. 3. pp. 312-43.

Elijido-Ten, E., Kloot, S., \& Clarkson, P. (2010). Extending the application of stakeholder influence strategies to environmental disclosures: an exploratory study from a developing country. Accounting, Auditing, \& Accountability Journal, Vol. 23 No. 8. pp. 1032-1059.

Fairclough (1997) Fairclough, N. (1997). Media Discourse. Edward Arnold: London.

Gallhofer, S., \& Haslam, J. (2011). Emancipation, the spiritual and accounting. Critical Perspectives on Accounting, Vol. 22, No. 5. pp. 500-9.

Georgakopolus, G., \& Thomson, I. (2005). Exploring social, financial and ecological risks of the Scottish salmon industry. Accounting Forum, Vol. 29 No. 1. pp. 49-75.

Goswami, K., \& Lodhia, S. (2014). Sustainability disclosure patterns of South Australian Local Councils: a case study. Public Money \& Management, Vol. 34 No. 4. pp. 273-280.

Grabsch, C., Jones, M.J., \& Solomon, J.F. (2010). Accounting for biodiversity in crisis: a European perspective. paper presented in the 14th Financial Reporting and Business Communications Conference. The University of Bristol. Bristol.

Grabsch, C., Jones, M.J., \& Solomon, J.F. (2011). Accounting for biodiversity in crisis: a European perspective. paper presented at 34th EAA Annual Congress. 20-22 April. Rome: Italy.

Gray, R. \& Bebbington, J. (2001). Accounting for the Environment. Second Edition. London: SAGE Publication.

Gray, R., Owen, D., \& Adams, C. (1996). Accounting and Accountability: Changes and Challenges in Corporate Social and Environmental Reporting. Prentice Hall: Englewood Cliffs, NJ.

Gray, R.H. (1992). Accounting and environmentalism: an exploration of the challenge for gently accounting for accountability, transparency, and sustainability. Accounting, Organisations and Society, Vol. 17 No. 5. pp. 399-425.

Gray, R.H., Bebbington, K.J., \& Walters, D. (1993). Accounting for the Environment. Chartered Association for Certified Accountants. London.

Gray, R.H., Kouhy, R., \& Lavers, S. (1995). Corporate social and environmental reporting: a review of the literature and a longitudinal study of UK disclosure. Accounting, Auditing \& Accountability Journal, Vol. 8 No. 2. pp. 47-77.

Groves, C.R. (2003). Drafting a conservation blueprint: a practitioner's guide to planning for biodiversity. Island Press: Washington. D.C.

Guimaraes, T., \& Liska, K. (1995). Exploring the business benefits of environmental stewardship. Business Strategy and the Environment, Vol. 4. pp. 9-22.

Guthrie, J., \& Farneti, F. (2008). GRI sustainability reporting by Australian public sector organisations. Public Money and Management, Vol 28 (6). pp. 361-366.

Hackston, D., \& Milne, M.J. (1996). Some determinants of social and environmental disclosures in New Zealand companies. Accounting, Auditing and Accountability Journal, Vol. 9 No. 1. pp. 77-108.

Harte, G., \& Owen, D. (1991). Environmental Disclosure in the Annual Reports of British Companies: A Research Note. Accounting, Auditing \& Accountability Journal, Vol. 4 Issue: 3, https://doi.org/10.1108/09513579110144442

Hines, R. (1991). On valuing nature. Accounting, Auditing \& Accountability Journal, Vol. 4 No. 3. pp. 27-29.

Houdet, J., Pavageau, C., Trommetter, M., \& Weber, J. (2009b). Accounting for changes in biodiversity and ecosystem services from a business perspective: preliminary guidelines towards a Biodiversity Accountability Framework. available at: 
www.economie.polytechnique.edu/Accueil/recherche/publications/Cahiers-derecherche/cashiers-2009-12861.kjsp?RH1/41249915206380 (accessed at 23 January 2017).

Houdet, J., Trommetter, M., \& Weber, J. (2009a). Changing business perceptions regarding biodiversity: from impact mitigation towards new strategies and practices. available at: www.economie.polytechnique.edu/Accueil/recherche/publications/Cahiers-derecherche/cashiers-2009-12861.kjsp?RH1/41249915206380 (accessed at 23 January 2017).

Jones, M. J. (1996). Accounting for Biodiversity: A Pilot Study. British Accounting Review, Vol.28. pp. 281-303.

Jones, M.J. (2003). Accounting for biodiversity: operationalising environmental accounting. Accounting, Auditing and Accountability Journal, Vol. 16 No. 5. pp. 762-789.

Jones, M.J. (2010). Accounting for the environment: towards a theoretical perspective for environmental accounting and reporting. Accounting Forum, Vol. 34. pp. 123-138.

Jones, M.J., \& Solomon, J.F. (2013). Problematising accounting for biodiversity. Accounting, Auditing and Accountability Journal, Vol. 26 No. 5. pp. 668-687.

Kelly, A.H. (2008). Management plans and state of environment reports prepared and implemented by local councils in NSW: problems and potential for biodiversity conservation. Building Resilience CIB International Conference on Building Education and Research. The University of Salford. School of the Built Environment. pp. 793-804.

Laine, M. (2009). Ensuring legitimacy through rhetorical changes? A longitudinal interpretation of environmental disclosures by a leading Finnish chemical company. Accounting, Auditing, \& Accountability Journal, Vol. 22 No. 7. pp. 1029-1054.

Lawrence, B. (2005). The context and causes of sprawl. Pp. 3-17. in Johnson, E.A., dan Klemens, M.W. editors. Nature in fragments: the legacy of sprawl. Columbia University Press: New York.

Lehman G. (1999). Disclosing new worlds: A role for social and environmental accounting and auditing. Accounting Organizations and Society, 24 (3). April pp. 217-242.

Magness, V. (2006). Strategic posture, financial performance and environmental disclosure: an empirical test of legitimacy theory. Accounting, Auditing \& Accountability Journal, Vol. 19 No. 4. pp. 540-563.

Marr, T. (2006). Triple Bottom Line: A Review for Local Government. Partnership Project Sydney Coastal Council Group Inc and the Institute of Environmental Studies. UNSW: Sydney.

Maunders, K.T., \& Burritt, R.L. (1991). Accounting and ecological crisis. Accounting, Auditing \& Accountability Journal, Vol. 4 No. 3. pp. 81-109.

Milne, M.J. (1991). Accounting, environmental resource values and non-market valuation techniques for environmental resources: A review. Accounting, Auditing \& Accountability Journal, 4(3). pp. 81-109.

Milne, M.J., \& Patten, D.M. (2002). Securing organisational legitimacy: an experimental decision case examining the impact of environmental disclosures. Accounting, Auditing, \& Accountability Journal, Vol. 15 No. 3. pp. 372-405.

Mobus, J.L. (2005). Mandatory environmental disclosures in a legitimacy theory context. Accounting, Auditing, \& Accountability Journal, Vol. 18 No. 4. pp. 492-517.

Mohninger, B. (2000). Approaches for Water and Energy Conservation in the Government of Jamaica. Ottawa.

O'Donovan, G. (2002). Environmental disclosures in the annual report-extending the applicability and predictive power of the legitimacy theory. Accounting, Auditing, \& Accountability Journal, Vol. 15 No. 3. pp. 344-371.

O'Dwyer, B. (2002). Managerial perceptions of corporate social disclosure: an Irish story. Accounting, Auditing \& Accountability Journal, Vol. 15 No. 3. pp. 406-436. 
Raar, J. (2014). Biodiversity and regional authorities: common-pool resources and accounting perspective. dalam Jones, M. (Ed.), Accounting for Biodiversity. Taylor and Francis. EBL Ebook Library: Hoboken. NJ. pp. 103-123.

Radeloff, V.C., Hammer, R.B., Stewart, S.I., Fried, J.S., Holcomb, S.S., \& McKeefry. J.F. (2005). The wildland-urban interface in the United States. Ecological Applications, Vol 15. pp. 799805.

Ramos, T., Alves, I., Subtil, R., \& Melo, J. (2007). Environmental performance policy indicators for the public sector: the case of the defence sector. Journal of Environmental Management, Vol. 82. pp. 410-432.

Roberts, C.B. (1991). Environmental disclosures: a note on reporting practices in mainland Europe. Accounting, Auditing \& Accountability Journal, Vol. 4 No. 3. pp. 62-71.

Rubinstein, D. (1992). Bridging the gap between green accounting and black ink. Accounting, Organizations and Society, Vol. 17 No. 5. pp. 501-508.

Sciulli, N. (2009). Sustainability reporting by local councils in coastal regions: an Australian study. Asian Journal of Finance and Accounting, Vol. 1 No. 1. pp. 76-86.

Solomon, J.F., \& Thomson, I. (2009). Satanic mills? An illustration of Victorian external environmental accounting? Accounting Forum, Vol. 33. pp. 74-87.

Steelman, T. A. (2002). Community-based involvement in biodiversity protection in the United States. pp. 142-167. dalam O'Riordan, T., \& Stoll-Kleemann, S. editors. Biodiversity, sustainability and human communities: protecting beyond the protected. Cambridge University Press: Cambridge, United Kingdom.

Tregidga, H. (2013). Biodiversity offsetting: problematisation of an emerging governance regime. Accounting, Auditing \& Accountability Journal, Vol. 26 No. 5. pp. 806-832.

Ullmann A.E. (1985). Data in Search of a Theory: A Critical Examination of the Relationships Among Social Performance, Social Disclosure and Economic Performance of US Firms. Academy of Management Review, 10 (3). Pp. 540-557.

United Nations (UN). (2010). Environmental Stewardship Strategy. United Nations Global Compact and Duke University. United Nations: New York, NY.

Williams, B., Wilmshurst, T., \& Clift, R. (2012). Sustainability reporting by local government in Australia: current and future prospects. Accounting Forum, Vol. 35 No. 3. pp. 176-186. 